\title{
End-to-side nerve repair using fibrin glue in rats $^{1}$
}

\author{
Anastomose nervosa término-lateral usando cola de fibrina em ratos
}

\author{
Daniel Nunes e Silva', Julice Coelho II, Fabrício de Oliveira Frazílio ${ }^{\mathrm{III}}$, Alexandre Nakao Odashiro ${ }^{\mathrm{IV}}$, Paulo de Tarso Camillo de \\ ${\text { Carvalhov, Elenir Rose Jardim Cury Pontes }{ }^{\mathrm{VI}} \text {, André Ferrão Vargas }}^{\mathrm{VII}}$, Marcelo Rosseto ${ }^{\mathrm{VIII}}$, Andréia Brochado Antoniolli da \\ Silva ${ }^{\text {III }}$
}

\footnotetext{
${ }^{\text {I }}$ Master Degree, Associate Professor, Department of Medicine, University for the State and Pantanal Region Development (UNIDERP), Campo Grande, Brazil.

II Associate Professor, Department of Physiotherapy, UNIDERP, Campo Grande, Brazil.

III Associate Professor, Department of Veterinary Medicine, UNIDERP, Campo Grande, Brazil.

${ }^{\text {Iv }}$ Associate Professor, Department of Medicine, UNIDERP, Campo Grande, Brazil.

${ }^{v}$ Associate Professor, Department of Physiotherapy, UNIDERP, Campo Grande, Brazil.

vi Associate Professor, Department of Collective Health, UFMS, Campo Grande-MS, Brazil.

${ }^{\text {VII }}$ Fellow Master Degree, Posgraduate Program in Neurology, Federal University of the State of Rio de Janeiro (Uni-Rio), Rio de Janeiro, Brazil.

VIII Associate Professor, Department of Surgical Clinics, UFMS, Campo Grande, Brazil.
}

\begin{abstract}
Purpose: To evaluate axonal regeneration after end-to-side nerve repair with fibrin glue in rats. Methods: Forty-five Wistar rats were divided into three groups: group A $(n=15)$, were not submitted to surgery (control group); group B ( $\mathrm{n}=15)$ were submitted to fibular transection without repair; and group $\mathrm{C}(\mathrm{n}=15)$, were submitted to fibular transection with end-to-side nerve anastomosis using fibrin glue, in the lateral surface of an intact tibial nerve. The three groups were submitted to walking track (30 and 90 days) and posterior morphometrical analysis (90 days). Results: The functional tests demonstrated that there was no difference in the walking track during the study in group A ( $>0.05)$. The group B had walking pattern impairment in the two tests ( $>0.05)$. The group $C$ had walking pattern impairment in the first test, with important recovery in the second test $(\mathrm{p}<0.05)$. The morphometrical assessment revealed significantly higher number of regenerated mielinates axons in group $\mathrm{C}$, compared to group $\mathrm{B}(\mathrm{p}<0.05)$. Conclusion: The end-to-side nerve repair with fibrin glue shows axonal recovery, demonstrated through functional and morphometrical ways in rats.
\end{abstract}

Key words: Suture Techniques. Fibrin Tissue Adhesive. Microsurgery. Rats.

\section{RESUMO}

Objetivo: Avaliar a regeneração axonal após anastomose nervosa término-lateral (ATL) usando cola de fibrina em ratos. Métodos: Quarenta e cinco ratos Wistar distribuídos em três grupos: os animais do grupo $\mathrm{A}(\mathrm{n}=15)$ não foram submetidos à secção nervosa (grupo controle); os animais do grupo $\mathrm{B}(\mathrm{n}=15)$ foram submetidos apenas à secção do nervo fibular, sem posterior anastomose; e os animais do grupo $\mathrm{C}(\mathrm{n}=15)$ foram submetidos à secção do nervo fibular e à ATL com cola de fibrina no nervo tibial. Posteriormente, os animais foram submetidos a dois testes de marcha (30 e 90 dias) e à análise morfométrica (90 dias). Resultados: A análise estatística dos testes de marcha demonstrou que o grupo A não apresentou alteração no padrão de caminhada durante o estudo ( $p>0,05)$. O grupo B apresentou prejuízo motor no primeiro e no segundo teste $(\mathrm{p}>0,05)$. $\mathrm{O}$ grupo $\mathrm{C}$ apresentou um padrão de atrofia no primeiro teste, com recuperação da marcha no segundo teste $(\mathrm{p}<0,05)$. Na análise morfométrica, o grupo $\mathrm{C}$ apresentou regeneração axonal significativamente superior ao grupo B $(\mathrm{p}<0,05)$. Conclusão: A ATL realizada com cola de fibrina resultou em regeneração axonal no rato, demonstrada tanto histologicamente quanto funcionalmente.

Descritores: Técnicas de Sutura. Adesivo Tecidual de Fibrina. Microcirurgia. Ratos.

${ }^{1}$ Research performed at the Surgery Techniques Experimental Laboratory, Federal University of Mato Grosso do Sul (UFMS) and Posgraduate Program in Health and Development, Midwest Region, UFMS, Brazil.

\section{Introduction}

In 1992, Viterbo obtained axonal regeneration by using end-to side neurorrhaphy without epineural window ${ }^{1}$. Despites being widely used ${ }^{2,3}$ the technique is considered controversial in literature ${ }^{4,5}$. Some authors question the quality of axonal regenera-

tion obtained and others could not repeat Virtebo's ${ }^{6}$ findings.

As end-to-side neurorrhaphy requires sutures, it presents disadvantages such as local trauma, granuloma formation, microscopic material instrumentation and extended surgical 
time $^{7,8}$. These aspects might justify some unsuccessful attempts of the technique and some contradictory elements in literature 9

Looking for successful surgical procedures, many studies have been performed in order to minimize the use of suture in nerve anastomosis ${ }^{1,6}$. The fibrin glue has been studied as an alternative to suture in end-to-end nerve anastomosis ${ }^{10}$. Its usage may improve the results as it is atraumatic, can be performed without a microscope and reduces surgical time ${ }^{9}$.

The role of fibrin glue at end-to-side nerve repair has not been completely established ${ }^{9,10}$. Despite the few experimental studies available in literature its clinical usage has been reported to be successful ${ }^{5}$. Therefore, the aim of this study is to evaluate the axonal recovery after end-to-side anastomosis using fibrin glue in rats.

\section{Methods}

The study was approved by the Experimental Research Ethics Commission of the Federal University of Mato Grosso do Sul (UFMS) following international rules ${ }^{11}$. The experiment was performed at the Surgery Techniques Experimental Laboratory of the Faculty of Medicine, UFMS, from May to December 2007.

The experiment was performed with forty-five adult male Wistar rats (Rattus norvegicus albinos) ranging from 130 to 150 days old and weighing from 275 to 294 grams. The rats were supplied by the UFMS animal colony.

The animals were divided into three groups: A, B and C. The animals in group $A(n=15)$ were not submitted to surgery. They were kept under observation as control group. The animals in group $B(n=15)$ were submitted to fibular transection without repair. The animals in group $\mathrm{C}(\mathrm{n}=15)$ were submitted to fibular transection and end-to-side nerve anastomosis with fibrin glue, in the lateral surface of an intact tibial nerve (without epineural window).

The animals in groups $\mathrm{B}$ and $\mathrm{C}$ were anesthesied with Ketamin $(50 \mathrm{mg} / \mathrm{k})$ and Xylazin $(50 \mathrm{mg} / \mathrm{k})$ by intraperitonial injection.

The surgical access to the fibular nerve was performed by a longitudinal incision measuring approximately four centimeters long at the upper-lateral aspect of the left pelvic limb (LPL) (Figure 1).

The fibular nerve was transectioned with micro scissors at three millimeters from its origin in the sciatic nerve. The stump was bended in an approximately $100^{\circ}$ angle and fastened with a single polyamide 7.0 stitch in the abductor musculature. (Figure 2).

The animals in group B were not submitted to repair

The animals in group $\mathrm{C}$ were submitted to an end-to-side nerve anastomosis using fibrin glue with preservation of epineuro according to the technique described by Mueller ${ }^{9}$, based on Viterbo ${ }^{1}$ end-to-side nerve anastomosis. The distal stump of the fibular nerve suffered nerve repair to the lateral face of the tibial nerve 4 millimeters from its origin. It was used Tissucol ${ }^{\circledR}$ fibrin glue (Baxter AG, Vienna, Austria) ${ }^{8}$ (Figure 3).

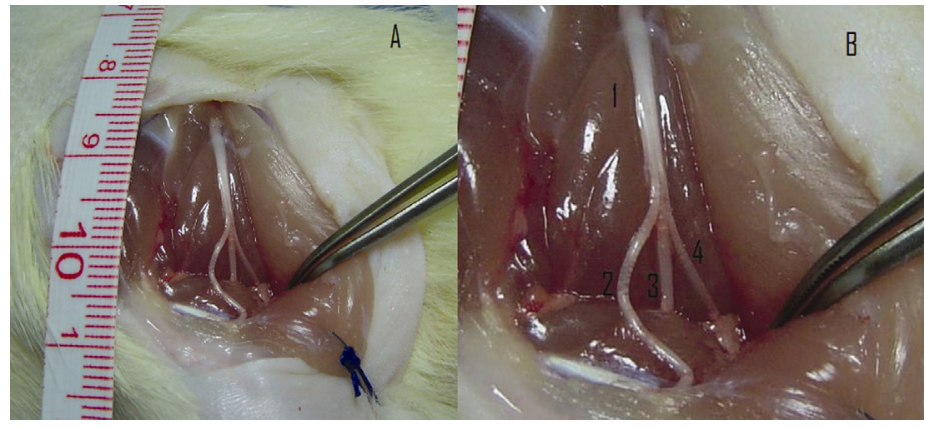

FIGURE 1 - Trans-operatory picture dissection: identification of the sciatic nerve and its terminal branches. A) Aspect of LPL anatomical dissection after the rupture of the superficial musculature. B) Identification of the sciatic nerve (1), fibular nerve (2), tibial nerve (3) sural nerve (4)

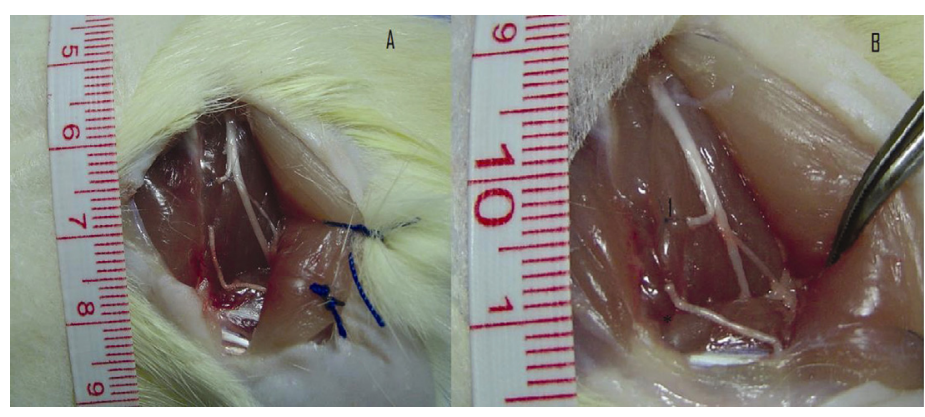

FIGURE 2 - Trans-operatory picture of a group B animal: repair-sham operation. A) Sectioned fibular nerve. B) Detail showing the proximal stump in the fibular nerve (1) and distal stump $(*)$ not submitted to repair

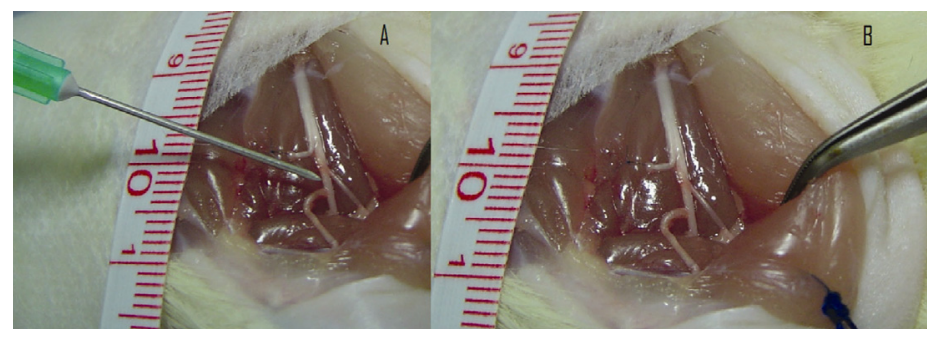

FIGURE 3 - Trans-operatory picture of a Group C animal. A) Fibrin glue application. B) Aspect of end-to-side nerve anastomosis after application fibrin glue

The skin was sutured with 4-0 polyamide monofilament continuous stitches.

The right pelvic limb (RPL) was not submitted to surgery.

The surgery procedure was performed by the same researcher with microsurgery equipment and magnifying glass enlarging 4,5 times.

The second stage of the study started on the thirtieth day: the analysis of the motor function by means of the walking track analysis $^{12}$, including groups $\mathrm{A}, \mathrm{B}$ and $\mathrm{C}$.

The animals were placed on a walking down corridor (11,5 x $50 \mathrm{~cm}$ ) with access to a dark environment. A cardboard sheet was placed on top of the corridor. The animals had their hinder paws painted and, as they walked, they left prints.

Four consecutive prints per animal were analyzed. The measurements used to calculate the function indexes were: distance between the talus and the third distal phalange ( $\mathrm{PL}=$ print length); distance between the first and the fifth distal phalange (TS = toe 
spreading) and distance between the second and the fourth distal phalange (ITS = intermediary toe spreading).

According to the measurements taken the function index were calculated to determine the motor recovery of the animals. The indexes analyzed were Toe Spreading Test (TST) ${ }^{12}$, Print Length Factor $(\mathrm{PLF})^{7}$, the Fibular Index (IF) ${ }^{13}$ and the Sciatic Function Index (SFI) ${ }^{14}$.

According to TST interpretation, the complete motor function loss results in an index smaller or equal to $30 \%$. A $50 \%$ motor function loss is related to a $65 \%$ TST. The absence of motor loss is related to a $100 \% \mathrm{TST}^{12}$.

According to PLF interpretation, values close to zero, 90 days after surgery, indicate preserved motor function. The smaller is the index, the higher is the function loss?

According to IF interpretation the values close to zero represent normal fibular nerve function and values close to -100 (minus 100) indicate complete dysfunction ${ }^{13}$.

According to SFI interpretation values close to zero are considered normal and values close to -100 (minus 100) indicate complete lesion of the nerve or absent nervous regeneration ${ }^{14}$.

The walking track analysis was repeated ninety days later for comparison criteria. The researcher responsible for the walking track analyses was not informed about which group the animals belong in neither tests.

The animals were sacrificed with lethal dose of sodic pentobarbital $(75 \mathrm{mg} / \mathrm{k})$ by intraperitoneal injection. Following the methodology used in the first procedure, a new incision was performed with disruption of the structures up to identification of the study area.

Nervous segments were removed for histological analyses from the extremity of the sciatic nerve and from the tibial and the fibular nerves. The microscopic slides were produced by means of fibular nerve transections $8 \mathrm{~mm}$ from its origin in group A, $5 \mathrm{~mm}$ from its distal stump in group B and at $5 \mathrm{~mm}$ from the end-to-side nerve repair with tibial nerve in group $\mathrm{C}$.

The samples were included in paraffin and cut with microtome - five micrometers thick. Slides with four sectional cuts were obtained from each anatomical piece and dyed with hematoxylin-eosin $(\mathrm{HE})^{9}$. The quantitative analysis of the axonal recovery was performed by means of digitizing the four fields of each slide (enlarged 400 times). Each field, delimitated by computer, presented 97.98 square micrometers. The morphometric analysis was performed by means of Image Pro Plus $4.5^{\circledR}$ program and evaluated the number as well as the diameter of the myelinated axons per field 9 .

The obtained data was analyzed with the BioEstat 4.0 program. ANOVA and Kruskal Wallis (a posteriori Student Newman Keuls) tests were used to compare groups A, B and C. The comparison between the periods $\left(30^{\text {th }}\right.$ and $90^{\text {th }}$ days $)$ was performed by means of Wilcoxon test for related samples. The significance level adopted was $5 \%$.

\section{Results}

During the study period, wound infection rate was zero and no animal died. There was no statistic difference related to mean weight of the groups in the begging and at the end of the study. In the begginig of the study, the mean weight of the groups was aproximatelly $280 \mathrm{~g}$ ( $p=0,190$ ANOVA) and at the end of the study, ninety days after, was approximately $430 \mathrm{~g}$ $(p=0,934$ ANOVA $)$.

The analysis of the walking track test results (Table 1) using the function index showed that group $\mathrm{C}$ presented, on the $30^{\text {th }}$ day, walking pattern similar to group B. However, on the $90^{\text {th }}$ day, group $\mathrm{C}$ presented similar walking pattern to group A, indicating recovery. Comparative pictures on the $30^{\text {th }}$ and the $90^{\text {th }}$ days of the study illustrate the walking pattern of the groups in Figure 4.

On the morphometric analysis (Table 2), group $\mathrm{C}$ presented axonal recovery significantly superior to group $\mathrm{B}$, showing the effectiveness of end-to-side nerve repair using fibrin glue. Histological analisys of fibular nerves of groups A, B and C animals are shown in Figure 5.

TABLE 1 - Analysis of the average index values obtained on the walking track test on the 30th and the 90th days of the study

\begin{tabular}{|c|c|c|c|c|c|c|c|c|}
\hline \multirow{3}{*}{$\begin{array}{l}\text { Walking } \\
\text { track test }\end{array}$} & \multirow{3}{*}{ Day } & \multicolumn{6}{|c|}{ GROUPS } & \multirow{3}{*}{$\begin{array}{c}p(1) \\
(\mathrm{A} X \mathrm{~B} X \mathrm{C})\end{array}$} \\
\hline & & \multicolumn{2}{|c|}{$\mathrm{A}(\mathrm{n}=15)$} & \multicolumn{2}{|c|}{ B (n=15) } & \multicolumn{2}{|c|}{$\mathrm{C}(\mathrm{n}=15)$} & \\
\hline & & AVERA & $\mathrm{DP}$ & AVERA & E DP & AVERA & DP & \\
\hline \multirow{3}{*}{ PLF } & 30 & a 0,00 & 0,02 & a $-0,02$ & 0,11 & a $-0,02$ & 0,03 & 0,182 \\
\hline & 90 & $a-0,02$ & 0,05 & $\mathrm{~b}-0,18$ & 0,11 & $\mathrm{a}-0,02$ & 0,04 & $<0,001$ \\
\hline & $p(2)(30 \mathrm{X} 90)$ & \multicolumn{2}{|c|}{0,116} & \multicolumn{2}{|c|}{$<0,001$} & \multicolumn{2}{|c|}{0,975} & \\
\hline \multirow{3}{*}{ TST } & 30 & a 100,50 & 5,10 & b 62,50 & 9,40 & b 60,8 & 10,70 & $<0,001$ \\
\hline & 90 & a 100,20 & 4,20 & b 55,70 & 3,30 & a 95,80 & 3,80 & $<0,001$ \\
\hline & $p(2)(30 \times 90)$ & \multicolumn{2}{|c|}{0,865} & \multicolumn{2}{|c|}{0,036} & \multicolumn{2}{|c|}{$<0,001$} & \\
\hline \multirow{3}{*}{ IF } & 30 & $a-13,08$ & 4,89 & $b-46,66$ & 22,17 & b - $-47,63$ & 10,35 & $<0,001$ \\
\hline & 90 & a $-17,22$ & 10,20 & b - 78,06 & 18,66 & a $-20,45$ & 6,97 & $<0,001$ \\
\hline & $p(2)(30 \times 90)$ & \multicolumn{2}{|c|}{0,256} & \multicolumn{2}{|c|}{$<0,001$} & \multicolumn{2}{|c|}{$<0,001$} & \\
\hline \multirow{3}{*}{ SFI } & 30 & a $-8,01$ & 5,45 & b - 57,14 & 11,63 & b $-57,88$ & 11,09 & $<0,001$ \\
\hline & 90 & $a-8,22$ & 5,36 & b - $-65,85$ & 7,50 & a $-12,90$ & 5,04 & $<0,001$ \\
\hline & $p(2)(30 \times 90)$ & \multicolumn{2}{|c|}{0,776} & 0,2 & & \multicolumn{2}{|c|}{$<0,001$} & \\
\hline
\end{tabular}

Note: if $p \leq 0,05$ - statistically significant difference. $p(1)$ Kruskal Wallis and a posteriori Student Newman Keuls for comparing among groups $(\mathrm{A} \times \mathrm{B} \times \mathrm{C}$ ). Different letters indicate statistically significant difference. $p(2)$ Wilcoxon test for comparing between the evaluated periods ( $30 \mathrm{X} 90$ days) in each group. 


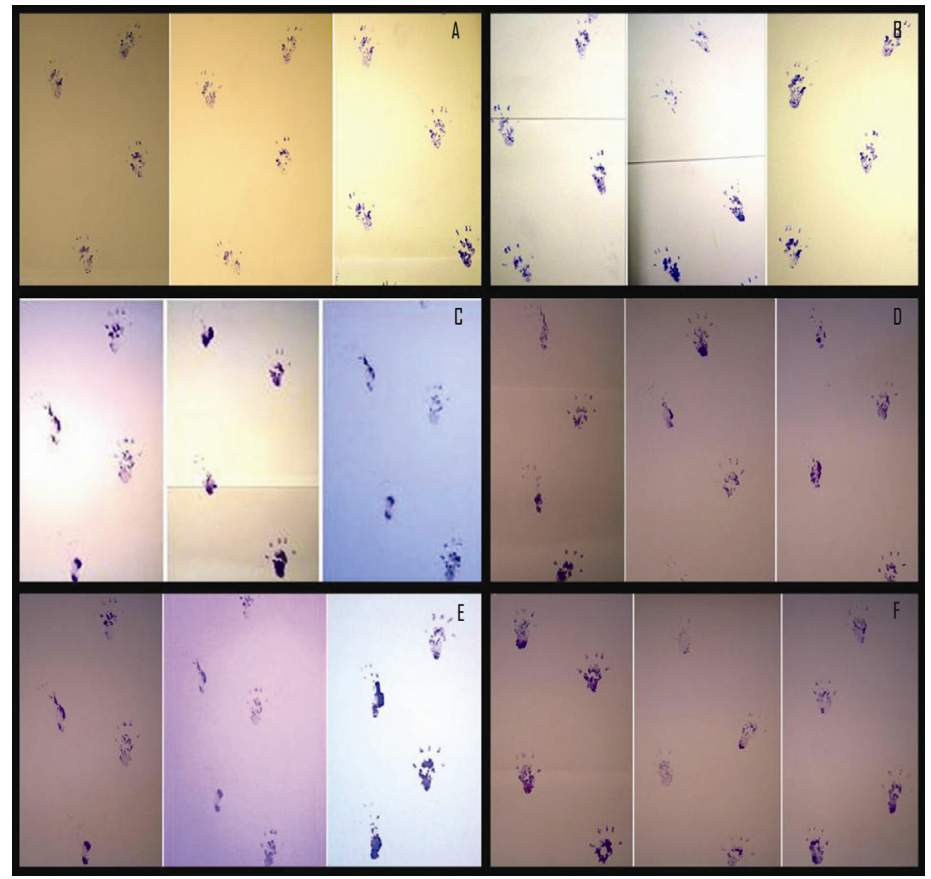

FIGURE 4 - Comparison among the prints of groups A, B and C in the first and the second walking track tests: detailed appearance of the prints of three animals on the 30th and the 90th days. Prints of a group A animal, on the 30th (A) and the 90th days (B), showing their symmetry. Prints of a Group B animal, showing atrophy of the LPL on the 30th (C) and 90th days (D). Prints of a Group C animal, showing atrophy of the LPL on the 30 th $(\mathbf{E})$ day and functional recovery on the 90th day $(\mathbf{F})$

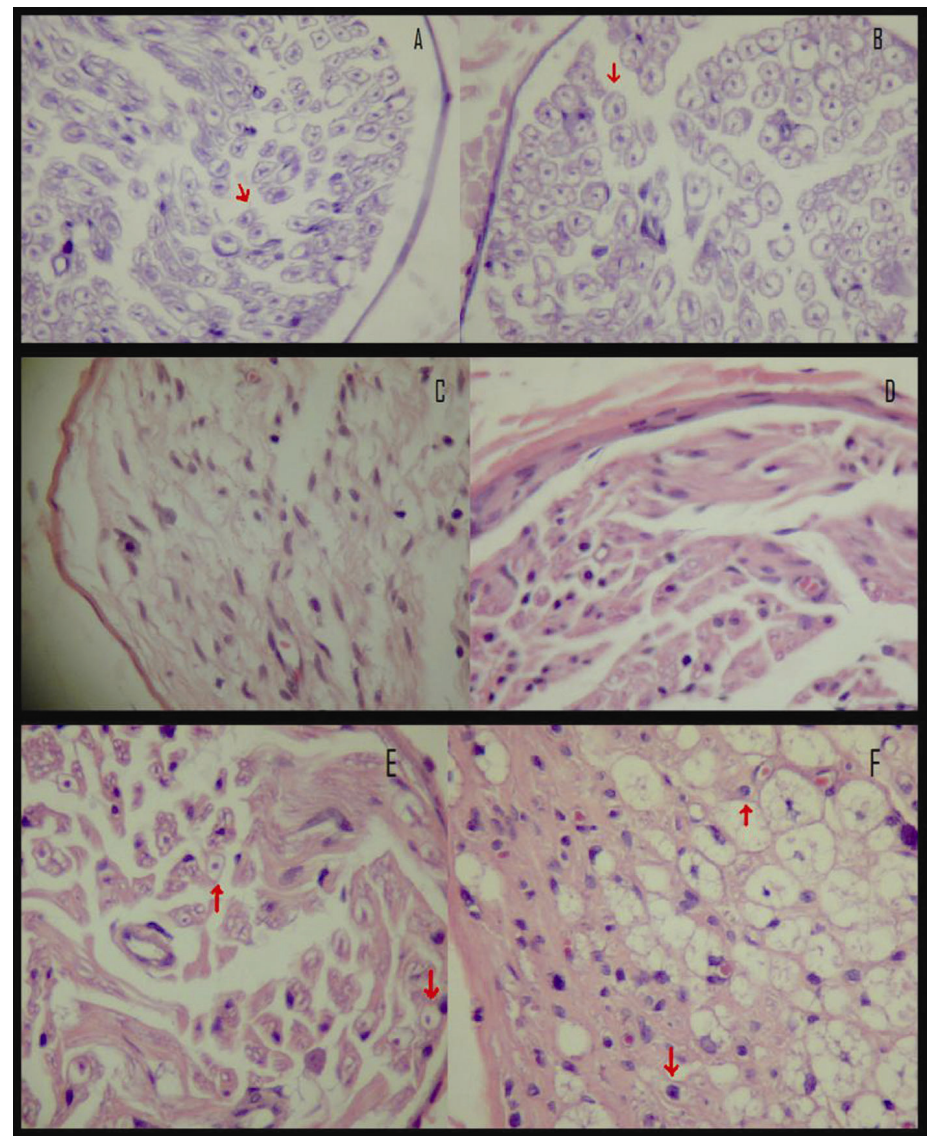

FIGURE 5 - Fibular nerve histological photomicrography of Groups A, B and $\mathrm{C}$. The red arrows represent examples of mielinic axons. (Dying: Hematoxylin-Eosin; 400 time enlargement)

TABLE 2 - Number and diameter of myelinated axons average values per field on the 90th day of the study

\begin{tabular}{|c|c|c|c|c|c|c|c|}
\hline \multirow{3}{*}{ Axons } & \multicolumn{6}{|c|}{ GROUPS } & \multirow{3}{*}{$\begin{array}{c}p(1) \\
(\mathrm{A} X \mathrm{~B} \text { X C) }\end{array}$} \\
\hline & \multicolumn{2}{|c|}{$\mathrm{A}(\mathrm{n}=15)$} & \multicolumn{2}{|c|}{$B(n=15)$} & \multicolumn{2}{|l|}{$C(n=15)$} & \\
\hline & AVERAGE & $\mathrm{DP}$ & AVERAGE & $\mathrm{DP}$ & AVERAGE & $\mathrm{DP}$ & \\
\hline Average number & 106,57 & 2,57 & 4,86 & 4,06 & 86,95 & 10,92 & $<0,001(\mathrm{~A}>\mathrm{C}>\mathrm{B})$ \\
\hline Average diameter & 9,64 & 1,14 & 2,68 & 2,46 & 7,69 & 0,90 & $<0,001(\mathrm{~A}>\mathrm{C}>\mathrm{B})$ \\
\hline
\end{tabular}

Note: if $p \leq 0,05$ - statistically significant difference. $p$ (1) Kruskal Wallis and a posteriori Student Newman Keuls.

\section{Discussion}

The functional analysis as well as the morphometric analysis confirmed the effectiveness of end-to-side nerve anastomosis using fibrin glue.

Mueller ${ }^{9}$ obtained axonal recovery - confirmed by histology - after end-to-side nerve anastomosis using fibrin glue with similar results to the group submitted to end-to-side neurorrhaphy. The author obtained an average number of $55.81+$ 19.87 axons per field and 5.51+1.9 micrometers of average axonal diameter for a group identical to group C. However, the author did not perform function tests on the animals, hindering comparative analysis.

Nevertheless, Bertelli et al. ${ }^{10}$ studied nerves of upper limbs in rats nerves and did not obtain axonal recovery after end-to-side nerve anastomosis using fibrin glue. However, those authors analyzed animals with only 30 days of post-operatory and did not include a comparative group in their study.

The main questioning about end-to-side nerve anastomosis is concerned to the axonal sprouting mechanism from the donor nerve which goes through a real barrier formed by endoneurium, peurineirium and epineurium until reaching the receptive nerve ${ }^{15}$.

According to many authors, a lesion on the nerve resulting from an "epineural window" or even by the minimal lesions (orifices) caused by the neurorrhaphy needle - is essential for the success of the technic ${ }^{16,17}$. According to Liu et al. ${ }^{16}$, those small lesions would be enough to increase contact between the nerves and induce release of growth factors, contributing decisively for axonal sprouting. Robillard et al. ${ }^{17}$ were skeptical in relation to the possibility of axonal sprouting without at least a minimal lesion on the donor nerve. 
The results of the present study confirm the findings of Akeda et al. ${ }^{18}$ and Matsumoto et al. ${ }^{19}$ who verified axonal recovery even in a protected end-to-side neurorrhaphy model (noninjurious end-to-side neurorrhaphy models). It is understood that the lesion on the donor nerve, even a minimal one, may damage it and prejudice the nerve repair; therefore, it should be avoided $^{15,16,19}$. The recovery obtained in group $\mathrm{C}$ supports the theory that the glue can be used in end-to-side nerve anastomosis, even and mainly without damaging the donor nerve?

The reproducibility of the findings in experimental studies for human beings is questioned. Liu et al. ${ }^{16}$ were specific when referring to the fact that in humans the thickness of the epineurium, perineurium and even the endoneurium would prejudice the axonal sprouting with this technique. However Samii et al. ${ }^{5}$ in 2006 reported a successful clinic case of end-to-side nerve anastomosis using fibrin glue in a vestibular schwannoma operation.

Millesi and Schmidhammer ${ }^{20}$ state that the controversies about the techniques are based on its complexity and on the innumerous variables involved in the process. Therefore, more studies are necessary due to the importance of the theme, the diverging findings in literature and the results presented here.

\section{Conclusion}

The end-to-side nerve repair performed using fibrin glue resulted in axonal recovery in rats, which was histologically and functionally documented.

\section{References}

1. Viterbo F, Trindade JC, Hoshino K, Mazzoni Neto A. Latero-terminal neurorrhaphy without removal of the epineural sheath. Experimental study in rats. Rev Paul Med. 1992;110(6):267-75.

2. Rovak JM, Cederna PS, Kuzon WM Jr. Terminolateral neurorrhaphy: a review of the literature. J Reconstr Microsurg. 2001;17(8):615-24.

3. Rosseto M, Fagundes DJ, Taha MO, Souza HS, Aydos RD, Guimarães RB, Novo NF, Juliano Y. Regeneration of peripheric nerves after end-toside anastomosis, maintaining epineuron, in rats. Acta Cir Bras. 2001;16(3):155-9.

4. Bertelli JA., Ghizoni MF. Concepts of nerve regeneration and repair applied to brachial plexus reconstruction. Microsurgery. 2006;26(4):230-44. 5. Samii M, Koerbel A, Safavi-Abbasi S, Di Rocco F, Samii A, Gharabaghi A. Using an end-to-side interposed sural nerve graft for facial nerve reinforcement after vestibular schwannoma resection. J Neurosurg. 2006;105(6):920-3.
6. Pardini Jr AG, Freitas AD, Plentz EG. Avaliação da sensibilidade após neurorrafia término-lateral de nervos digitais: nota prévia. Rev Bras Ortop. 2005;40(9):543-54.

7. Ornelas L, Padilla L, Di Silvio M. Fibrin glue: an alternative technique for nerve coaptation - Part I. Wave amplitude, conduction velocity, and plantar-length factors. Reconstr Microsurg. 2006;22(2):119-22.

8. Ornelas L, Padilla L, Di Silvio M. Fibrin glue: an alternative technique for nerve coaptation - Part II. Nerve regeneration and histomorphometric assessment. J Reconstr Microsurg. 2006;22(2):123-8.

9. Taha MO, Mueller SF, Fraga MM, Rosseto M, Fagundes DJ, Juliano Y, Caricati-Neto A. Morphologic analysis of the fibular nerve repaired with fibrin adhesive. Transplant Proc. 2004;36(2):401-3.

10. Bertelli JA, dos Santos AR, Calixto JB. Is axonal sprouting able to traverse the conjunctival layers of the peripheral nerve? A behavioral, motor, and sensory study of end-to-side nerve anastomosis. J Reconstr Microsurg. 1996;12(8):559-63.

11. Committee on care and use of laboratory animals of the institute of laboratory animal resources commission on life sciences: Guide for the care and use of laboratory animals. NIH Publication, Bethesda, Public Health Services, National Institute of Health; 1985.

12. Medinaceli L, Quach T, Duchemin AM. Is vigor of regeneration a key factor in recovery from peripheral nerve injuries? Exp Neurol. 1982;94:788-90. 13. Lowdon IM, Seaber AV, Urbania K. Jr. An improved method of recording rat tracks for measurement of the sciatic functional index of de Medinaceli. J Neurosci Methods. 1988;24:279-81.

14. Lago O Jr, Bortolletto CV, Araújo AM, Donoso CPM, Kume PK, Repka JCD. Avaliação funcional e histológica do reparo de nervo ciático utilizando cola de fibrina e sutura em ratos Wistar. Rev Bra Ortop. 2005;40(1):69-78. 15. Hayashi A, Yanai A, Komuro Y, Nishida M, Inoue M, Seki T. Collateral sprouting occurs following end-to-side neurorrhaphy. Plast Reconstr Surg. 2004;114(1):129-37.

16. Liu K, Chen LE, Seaber AV, Goldner RV, Urbaniak JR. Motor functional and morphological findings following end-to-side neurorrhaphy in the rat model. J Orthop Res. 1999;17(2):293-300.

17. Robillard BG, Myckatyn TM, Mackinnon SE, Hunter A. End-to-side neurorrhaphy and lateral axonal sprouting in a long graft rat model. Laryngoscope. 2002;112:899-905.

18. Akeda K, Hirata H, Matsumoto M, Fukuda A, Tsujii M, Nagakura T, Ogawa S, Yoshida T, Uchida A. Regenerating axons emerge far proximal to the coaptation site in end-to-side nerve coaptation without a perineurial window using a T-shaped chamber. Plast Reconstr Surg. 2006;117(4):1194-203. 19. Matsumoto M, Hirata H, Nishiyama M, Morita A, Sasaki H, Uchida A. Schwann cells can induce collateral sprouting from intact axons: experimental study of end-to-side neuroraphy using a y-chamber model. J Reconstr Microsurg. 1999;15:281-5.

20. Millesi H., Schmidhammer R. End-to-side coaptation - controversial research issue or important tool in human patients. Acta Neurochir Suppl. 2007;100:103-6.

\section{Correspondence:}

Conflict of interest: none André Ferrão Vargas Financial source: none

Rua Djalma Ulrich, 370/604

22071-020 Rio de Janeiro - RJ Brazil

Phone: $(55$ 21)3202-9300

Mobile: (55 21)9101-1232

Fax: (55 21)3202-9349

andreferraovargas@hotmail.com

Received: September 10, 2009

Review: November 18, 2009

Accepted: December 16, 2009

\section{How to cite this article}

Silva DN, Coelho J, Frazílio FO, Odashiro NA, Carvalho PTC, Pontes ERJC, Vargas AF, Rosseto M, Silva ABA. End-to-side nerve repair using fibrin glue in rats. Acta Cir Bras. [serial on the Internet] 2010 Mar-Apr;25(2). Available from URL: http://www.scielo.br/acb 